University of Rhode Island

DigitalCommons@URI

Open Access Master's Theses

1990

\title{
An Analysis of Two Types of Commitment That Bring an Objective Bond Into Existence
}

Mary Jo Brzozowski

University of Rhode Island

Follow this and additional works at: https://digitalcommons.uri.edu/theses

\section{Recommended Citation}

Brzozowski, Mary Jo, "An Analysis of Two Types of Commitment That Bring an Objective Bond Into Existence" (1990). Open Access Master's Theses. Paper 1544.

https://digitalcommons.uri.edu/theses/1544

This Thesis is brought to you for free and open access by DigitalCommons@URI. It has been accepted for inclusion in Open Access Master's Theses by an authorized administrator of DigitalCommons@URI. For more information, please contact digitalcommons-group@uri.edu. 


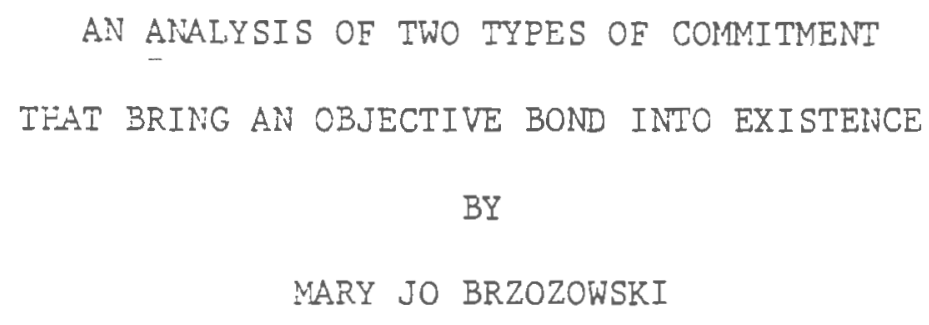

A THESIS SUBMITTED IN PARTIAL FULFILLMENT OF THE REQUIREMENTS FOR THE DEGREE OF MASTER OF ARTS

IN PHILOSOPHY

THE UNIVERSITY OF RHODE ISLAND 1990 22782407 


\begin{abstract}
The problem is to elucidate the nature of two types of commitments that involve an objective bond, the promise and the vow. The basis for the discussion is an article by Adolf Reinach, "The Apriori Foundations of Civil Law". Promising and the promise are compared and contrasted with vowing and the vow.

The method used is an attitude of openness to the data which present themselves. The essential chararcteristics of these entities are examined.
\end{abstract}




\section{ACKNOWLEDGEMENT}

I would like to acknowledge the numerous individuals who have made the completion of the thesis possible. I would like first of al1 to thank Dr.Fritz Wenisch, my major professor, for a11 of his he $1 \mathrm{p}$, encouragement, and support. He always had time for my questions and concerns. A thank you also goes to Dr.Mark Roberts, for his many helpful suggestions and for his support. Thanks to Dr.Bailey for agreeing to be on my thesis committee and for his patience with my hectic schedule, and thank you to Dr.Brownell for chairing the defense. I cannot forget to thank my brother, Mark Brzozowski, for his encouragement and help with a lot of footwork that needed to be done. A special thank you to my mother, Lia Brzozowski, who has always encouraged me to do my best and whose love for philosophy has inspired me to pursue it. And a final note of thanks to my fiance, Darryl Klein, whose constant support, understanding, and help in innumerable ways has enabled me to finish this thesis. 
TABLE OF CONTENTS

1. Chapter One: Introduction; pages $1-3$

2. Chapter Two: The Act of Promising; pages 4-13

3. Chapter Three: The Promise as the Product of the Act of Promising; pages $14-19$

4. Chapter Four: Question That Arise on the Basis of the Above Analysis; pages $20-48$

5. Chapter Five: An Analysis of the Making of a Marriage Vow and the Marriage Vow as Compared and Contrasted with Promising and the Promise; pages 49-54

6. Chapter Six: Questions that Arise on the Basis of the Above Ana1ysis; pages $55-66$ 


\section{CHAPTER ONE: INTRODUCTION}

The term "commitment" is a general one referring to a type of bond which comes into existence through an act of the person. The type of act determines the type of comitment. Conmitments can be divided into two major types: those which involve an objective bond, and those which do not. The term "objective," as it will be used in this paper, should be understood as referring to a bond which has an extra-mental existence, and which comes into existence automaticaliy through a particular act of the person, independent $1 y$ of an individual's desires or the laws of a particular society, and which continues to exist independently of an individual's desires or the laws of a society. 1 The term "objective" can have a meaning which does not coincide with the above definition of "objective". This, together with the sense in which a bond that would be objective in one sense can also be called "subjective" in another sense, will be discussed below.

A commitment that does not involve an objective bond could be, for example, a commitment to an ideal or to a way of life. Here it could be that a person merely makes an internal resolution to be committed. If the commitment is taken seriously, he will make the idea 1 a priority in a 11 the relevant decisions that he makes. As will be seen, a purely internal resolution is not a type of act that can bring an objective claim and obligation into existence. 
A type of act that can bring an objective claim and obligation into existence belongs to the class of what Reinach calis social acts. A social act is one which is not only directed to another person, but which is addressed to another person, and so needs to be announced. ${ }^{2}$ Promising is such an act; thus a type of commitment that does involve an objective bond is the promise.

The fresent discussion will be 1 imited to the type of commitments which do involve an objective bond. Specifically, the promise and the vow will be chosen for discussion.

It is important to recognize that there is a distinction between the act of promising and the promise itself, ${ }^{3}$ and similarly a distinction between the making of a vow and the vow itself. Clearly, promising, which can also be expressed as making a promise, brings the promise itself into existence. Similarly, vowing, or the making of a vow, brings a vow into existence. Care will be taken to never confuse the verb with the noun, so to speak. 4

It will be assumed throughout this paper that the promise and the vow are each identical to the obligatory relationship, or bond, that is brought into existence by promising or vowing. The nature of the act of promising and the promise itself will first be analyzed from Adolf Reinach's point of view which he explains in his article: "The Apriori Foundations of Civil Law". An exposition and further clarification will be made, and some related questions not discussed by Reinach will be addressed. On the basis of the above analysis, the making of a vow and the vow itself will next be ana1yzed. The analysis will be limited to one particular type of vow, the marriage vow. Thus a comparison and contrast between 
promising and the making of a marriage vow on the one hand, and between the promise and the marriage vow on the other, will be accomplished. 
CHAPTER TWO: THE ACT OF PROMISING

The nature of the act of promising and the promise itself are perfect targets for a philosophical analysis. Promising is an act with which everyone is somewhat familiar, but the complex nature of which is not often recognized and certainly not widely understood. Promising is one of those unique acts of the person that result in a bond. That a bond comes into existence is clear when it is recognized that promising creates an obligation for the one who promises, and a claim for the person to whom the promise is addressed: promising "...gives the person to whom it is made a right to expect or to claim the performance or forbearance of a specified act." 5 The claim and obligation are what constitute an "obligatory relationship" 6 which is what binds the two parties together. The nature of the act of promising has often been misunderstood. A common definition of promising is that it is a "declaration of wil1, or more exact1y, an expressing or making known the intention of doing or omitting something in the interest of another to whom the utterance is made." 7 Reinach points out a fundamental problem with this definition: why should the expression of one's intention result in an objective claim and obligation? While it is clear that a resolution to do something could result in a psychological bond, or inner tendency to act in accordance with one's resolution, this psychological bond does not entail an 
objective claim or obligation. Furthermore, Reinach says that he does not see why an objective claim and obligation should come into existence just because one has an intention which is somehow in the interests of another.

It is obvious to Reinach that the above difficulties in accounting for the existence of an objective claim and obligation result from a misunderstanding of the nature of promising from the outset: promising is not reducible to making known a decision of wi11, rather the two are fundamenta11y different from each other, in spite of the fact that they might make use of the same linguistic expressions. ${ }^{8}$ Actually, the fact that there can be a misunderstanding whereby a person thinks he has a claim against another person when in reality the other person has on $1 \mathrm{y}$ expressed his intention to do something instead of making a promise, attests to the fact that promising and making known one's intention are completely different. 9

If promising is, then, more than a simple declaration of intention, what exact1y is it? First of a11, Reinach points out that promising is not only an intentional act, in that it refers to some object, it is also a spontaneous act, which is a "doing of the self,"10 an act in which "the self shows itself to be the phenomenal originator of the act."11 Certain spontaneous acts, 1 ike the act of forgiving, or the act of intending, can but need not be expressed externa11y, while it is the nature of other spontaneous acts to need to be announced. These latter type of acts are called by Reinach 'social acts.' Promising is such an act. It is other-directed, and so presupposes a second subject to whom the act is related. It also 
addresses the other; the other must become aware of it, and for this reason promising needs to be external1y expressed. Reinach points out that it is only because of the nature of the human person that promising needs to be externally expressed. If it were possible for another person to become aware of the act of promising in another way, then the externa 1 expression would not be a requirement. 12

The act of promising has an inner and an outer side. It is not a purely inner experience, nor a purely external experience, nor simply the announcing of an inner experience, even if this inner experience were an intention, as was stated above. Reinach explains that the inner side of promising always remains the same, but the outer side can vary. Taking the outer side first, it is clear that a promise can be expressed by spoken word, written word, gestures, etc. 13

Characteristic of the expression of promising is that it is "completely subject to our voluntariness,"14 unlike other types of expressions which may be involuntary. 1ike crying or smiling. Further, the external expression of promising is not something optional which is simply added to an inner experience. Rather it is a voluntary utterance which forms an inner unity with the inner voluntary act. Reinach emphasizes this unity by stating that "...the inner experience here is not possible without the utterance."15

What is the nature of the inner side of the act of promising which Reinach has referred to as an inner experience? It cannot be a mere act of intending if promising is held to be more than an expression of intention. Rather, it must be the actual promising 
itself, the very act of binding the self to the performance or omission of a specific action which is "...performed in the very act of speaking..." 16 (Of course as mentioned above the spoken word is only one of the ways in which the inner side of promising can be expressed.)

The inner side of the act of promising must be more than simply an act of intending even if the act of intending is that of intending to make a promise. It might be helpful to consider an example. A person can intend to invite another person for dinner. He can also intend to promise to invite another for dinner. This second intention, even if expressed, is not an act of promising, nor is the unexpressed intention even the inner side of the act of promising. It remains a mere intention, even though it is an intention to promise.

In explicating the difference between an expression of an inner experience of accepting and a social act of accepting, Reinach arrives at certain distinctions between the two which seem also to apply to the differences between an intention to promise and the social act of promising itself. The first of these distinctions is that, while the expression of acceptance can be directed to anyone, the social act of acceptance must be directed toward the promisor. Secondly, the expression of acceptance can be meaningful1y repeated and directed towards many persons, but a social act of acceptance, as a response to a particular act of promising, can meaningfully be performed on $1 \mathrm{y}$ once. Finally, the expression of acceptance can refer to a past or present experience of accepting and so can be made in the past or present tense. The social act of acceptance, however, 
can on $1 y$ be made in the present tense. 17

An application of the above distinctions to the issue at hand can easily be made. The expression of an intention to promise, or simply the expression of an intention, can meaningful1y be directed to persons other than the promisee, while the same is not possible with the social act of promising. The expression of the intention to promise can be repeated and directed towards many persons, while the social act of promising can meaningfully be performed only once. In other words, if a person makes a promise to a friend and then repeats himself in order to make sure that the friend has not forgotten, there is not then more than one promise. Finally, the expression of an intention to promise refers to the future, and therefore is made in the future tense, while promising must be made in the present tense.

Furthermore, it is clear by the above that the expression of an intention to promise occurs without a promise coming into being. Take the following example: Sue says to Mary, "I've been wanting to have John over for dinner for a while now, but I get so busy. I've decided to promise him that I will invite him, and this way I wil1 make it a priority." Obvious $1 \mathrm{y}$, in this example a claim does not come into being for Mary, nor even for John. If Sue were to repeat the expression of intention to others, these other persons would also not thereby have claims. And the expression itse1f, which is made in the future tense, is meaningful. The future tense signifies that the promise has not yet been made. 
decide that she is too busy to make that promise to John, she could still change her mind. If she had made a promise, however, her obligation would remain whether it was inconvenient to fulfill or not. (There can be an exception to this last point. This exception, together with the question of how the situation should be evaluated if John happens to depend on Sue's intention, will be addressed below). Finally, the intention to promise is not a social act at a11, because an intention to promise need not be expressed.

Reinach next explains that a11 social acts, including the act of promising, presuppose internal experiences which do not necessarily express themselves to others, but are internal1y complete.18 The internal experience presupposed by the act of promising is an intention to do the thing promised, and this is expressed by Reinach when he says: "Every promising to do this or that, presupposes that one's will is directed to this action."19 Thus if a person promises his neighbor to watch his house while he is on vacation, as long as he is promising authentically, it must be that he intends to watch his neighbor's house.

Later, Reinach calls this internal experience of intending an "inner experience". He says,

Like all social acts, promising presupposes an inner experience which has the content of the promise as its intentional object. As with commanding, this inner experience is that of intending that something occur, not of course through the addressee but through the promisor himse $1 \mathrm{f} .20$

Reinach's calling the internal experience of intending which promising presupposes an 'inner experience' and applying the same term to the inner side of the act of promising can lead to 
confusion, especially since he wants to distinguish the two. It must be remembered that the inner side of the act of promising does necessarily express itself; it is not internally complete but must exist in unity with an utterance. Further, it is not a mere act of intending, but is rather the actual promising, the 'binding of the self'. The internal experience presupposed by promising, on the other hand, does not necessarily express itself but is internally complete, and is simply an act of intending.

It seems, then, that if Reinach's terminology is used, there are actually three 'inner experiences' involved with the act of promising. They are an intention to do ' $\mathrm{X}$ ', an intention to promise to do ' $\mathrm{X}$ ', and the inner side of the act of promising. The first two are internally complete, the last is not, as stated above. Although they are different, the intentional objects of each of them coincide or at least are related to each other. ${ }^{21}$ The intentional object is the content of the 'inner experience', that is, the specific act(s) which one has intended to perform or omit, and/or intended to promise to perform or omit, and/or promised to perform or omit. In other words, the internal1y complete inner experiences of intending to do "X", intending to promise to do "X", together with the inner side of the act of promising, all must refer to the same action. It is also clear that the outer side or external expression of promising must refer to the same action as these "inner experiences". If the promising is sincere, it presupposes an intention to promise to do "X", and the intention to promise presupposes an intention to do "X". 
CHAPTER THREE: THE PROMISE AS THE RESULT OF THE ACT OF PROMISING What must be explored next is the bond which comes into existence by the act of promising. It is the efficacy characteristic of promising, that promising brings an objective bond into existence, that "...something is thereby changed in the wor $1 \mathrm{~d}$ ", 22 that makes it such an amazing and interesting act of the person. As Von Hildebrand states, "Among the various human experiences there is one kind which is not merely an inner act in respect to another person such as love, respect, joy, and so on, but which creates an objective reality independent of the person." 23 This 'objective reality' is the promise itself, the bond which exists between the person who has the claim and the one who has the obligation. That the bond created by the act of promising must be objective should become clear as the nature of the bond is revealed. The term "objective" must first be clarified. In what sense can it be said that the bond created by the act of promising is objective? Something can be called "objective" and by this is meant that it has no dependence upon a person. For example, the fact that a particular atom has a certain amount of electrons is not dependent upon the existence of persons. The bond created by the act of promising is certainly not objective in this sense, for not on $1 \mathrm{y}$ is the bond created by an act of a person, it also is dependent upon the existence of the persons involved. In other words, except in 
certain cases which will be discussed below, if either the promisor or promisee dies, the promise also ceases to exist.

Secondly, something can be called "objective" and by this is meant that it is predicable of an object. The bond would be subjective in contrast to this definition of objective, because it is not a predicate of anything. It is, rather, a relation between the promisor and promisee.

The term "objective" is an opposite of the term "subjective," a1though one must be careful since the term "subjective" itself has more than one meaning. The bond created by the promising is not subjective in the sense of existing in the mind of a person, where this would entail the feelings and desires of a person being capable of affecting the existence of the bond. It seems patently obvious that the very essence of the promise precludes any dependence on feelings or desires. A promise does not cease to exist, for example, simply because the promisor no longer feels like fulfilling his obligation.

An objection might here be raised; it could be argued that a promise is in fact dependent upon feelings, because there is no obligation for the promisee to accept the claim, 24 and so if his feelings change, he can simply waive the promise. Although it is true that the promisee can waive the promise, it is not his change of feelings themselves which waive the claim, but rather it is an act by which he waives his claim. Of course, the reason for the act of waiving could very well be a change of feelings.

So in contrast to the above definition of "subjective," that is, existing in the mind of a person, the bond created by promising 
is objective. The bond is a1so objective in the sense that it comes into existence automatically through the act of promising, independent $1 \mathrm{y}$ of an individual's desires or the laws of a particular society, and continues to exist independently of an individual's desires or the laws of a particular society.

On the other hand the bond is "subjective" when this term is defined as having a relation to a person, or being somehow dependent upon the existence of a person. 25

What then is the nature of this bond, of the claim and obligation which are created by the act of promising? First of a11, Reinach explains that, although claim and obligation are obvious $1 \mathrm{y}$ not physical entities, neither are they merely psychical or mental experiences, and this for the following reasons: Claim and obligation "...can last for years without change, but there are no experiences which 1ast 1 ike this." 26 Claim and ob1igation exist even when one is not actively thinking about them, for example when one is as leep or unconscious. 27

Further, an obligation does not cease to exist if the promisor forgets that he has an obligation. Obviously forgetting that one has an obligation does not excuse one from it, except in some instances if the promisor has suffered a loss of rationality. This situation will be addressed below.

It is also clear that one does not lose a claim simply because one has forgotten about it. One could forget about a claim and yet demand fulfillment years later; this is because it is the promisor's responsibility to make sure that the obligation is 
fulfilled.

Claim and obligation can not be reduced to mere feelings of being obligated or of having a claim, because as Reinach points out, "Nothing is more certain than that I can very we11 fee1 myself to be obliged without there really being any obligation, and that on the other hand I can very wel1 have a claim without feeling myself to be entitled at the moment in which I have it." 28

Another possibility is that a person can have an obligation without feeling obliged. One can forget the obligation or perhaps talk oneself out of it, saying for example that the promisee does not rea11y care about the promise, or has forgotten about it and wil1 not care if it is not fulfilled. Neither of these affect the actual obligation in the 1east.

A fourth possibility is that one thinks one has a claim when one rea $11 y$ does not, as in the example mentioned above of the misunderstanding that can occur if a person thinks that a promise has been made when real1y no such promise exists. These four possible discrepancies between a person's belief and the actual state of affairs concerning claim and obligation demonstrates the fact that the promise exists independently of the beliefs, desires and even memories of both the promisor and promisee.

Next, claim and obligation are tempora1. ${ }^{29}$ They come into being at a certain point in time, and they each refer to a future action. A promise can, "...according to its essence, last ever so 1ong. but on the other hand it seems to have an inherent tendency towards meeting an end and a dissolution." 30 According to Reinach, a promise is dissolved if the obligation is fulfilled, which is the 
natural end of the promise, if the promisee waives the claim, or if the promisor revokes the promise. 31

On the other hand, although it is natural that the promise have an end in time by being fulfilled, it also can exist unaffected by time. That is, it can exist for years without change, as mentioned above.

Reinach holds that certain immediate1y inte11igible laws, laws which are at the same time a priori and synthetic, apply to claim and obligation. These laws are necessarily grounded in the essences of these entities. Two examples of such laws are the following: "A claim to have something done dissolves as soon as the thing is done," 32 and "a claim can on $1 \mathrm{y}$ arise in the person to whom the promise is addressed." 33 It seems that other so to speak parallel laws are that the obligation to do something dissolves as soon as the thing is done, and an obligation can on $1 \mathrm{y}$ arise in the person who makes the promise. (There is a possible exception to the second of these 1aws, when it comes to a promise which involves a third party. This will be discussed below.)

Next, claim and obligation presuppose universa11y and necessarily a bearer, and this bearer must be a person. ${ }^{34}$ since it does not seem to make much sense for a person to be obligated to himself, or to have a claim against himself, it seems that another requirement is that the same person cannot be bearer of both claim and obligation that stem from the same act of promising. 
it adresses another person and therefore involves more than one person. This precludes the possibility of a person being able to promise himself something. What is 1oosely called "promising oneself" to do something, for example promising oneself to lose weight, to do more reading, to try to be a better person, is actually an internal resolution. Since it is purely internal and therefore not a social act, it could not be called an act of promising according to Reinach's definition.

Claim and obligation presuppose universally and necessarily a definite content to which they refer. Every obligation refers to a future action of its bearer whether the action be a doing, omitting, or tolerating. 34 The action is to take place through the bearer of the obligation. Reinach explains that a person "...can be obliged that something take place through another. But here too it must be my action which is supposed to lead to the action of the other." 36 For example, a person can promise his parent to make sure that a younger sibling cleans his or her room.

A different situation from the one above would occur if a person promised a parent to take out the garbage, and then paid a younger brother to do it. Unlike in the first situation, the obligation is not specifical1y to take place through another. Has the promise been fulfilled? The answer to this question hinges on the wording of the promise. Saying, "I promise that I will take out the garbage," is different from saying, "I promise that the garbage wil1 be taken out." The latter wording clearly leaves the possibility open for getting someone else to fulfill the obligation. The promisor would, of course, still be obliged to make sure that 
the obligation is fulfilled.

Since claim and obligation must have identical content, 37 it is clear that every claim also refers to a future action, that is, to the same action to which the corresponding obligation refers.

Reinach explains that although the immediate content of the obligation is the action of the promisor, still this is not always its on $1 y$ or final content. There is, in other words, a difference between obligations which tend toward an action and find their fulfillment in it, and obligations which aim through the action at the realization of an end result. In the former case, the way of acting is necessarily determined. In the latter case, however, it is only the end result which is determined. An example of the former type of obligation is the following: A person knows how much his wife loves to dance, but it happens that she is so busy lately that she has not danced in a long time. At his request, she promises him to dance at least one time a week. Here, it is the dancing itself which fulfills the obligation, not some other end, like for example exercising.

An example of the second type of obligation, one which aims at the realization of an end result, is the following: A person promises his mother to get rid of an old car which has been in the driveway for months and does not run. It is up to the promisor to decide how to fulfill the obligation. He can have it towed away, fix it enough to drive it to the junkyard himself, sel1 it for parts, fix it and then sel1 it, etc. It is the absence of the car, no matter how that absence is effected, that will fulfil1 the 
obligation.

Of course it could be that both the action itself and the end result of the action are determined. An example of this would be if one promises to dance because one needs the exercise, but a specific reference to dancing is made. 
CHAPTER FOUR: QUESTIONS THAT ARISE ON THE BASIS OF THE ABOVE

\section{ANALYSIS}

There are many more things that can be said about the act of promising and the promise itself, but they cannot al1 be addressed here. Some questions that follow from the brief analysis given above wi11 now be examined.

\section{First of al1, Reinach had said that if promising is} understood as an expression of intention, then the fact that promising creates an objective claim and obligation can never be explained, even if it is assumed that the intention is somehow in the interests of another. There is a problem here however. Is it not true that an expression of intention can bring forth an objective claim and obligation? For example, what if a person relies on an expression of intention to such an extent that he would suffer harm as a result of a change of intention? Would the person who made the expression of intention not then have an obligation to refrain from changing it? Reinach provides the answer by explaining that a moral duty can very well arise in such a situation, but the ground of this duty is not the statement of intention but rather the fact that it is right to avoid harming another. The moral duty presupposes that its content is morally right. The obligation which is created by the act of promising, however, does not presuppose a moral1y right state of affairs. ${ }^{38}$ One has an obligation to take a 
friend out to dinner as a result of promising this action to the friend, but taking someone out to dinner is in itself moral1y neutral.

Of course the content of the promising does not have to be morally neutral, it could be morally right, as when a person who has a drinking problem promises his family to stop abusing alcoho1. It is morally wrong to abuse alcohol, and the promisor thus has a moral duty to stop doing so, but now since he has made a promise he has a further obligation to refrain from the abuse in order to fulfill the obligation of the promise. ${ }^{39}$ (A different situation altogether, that of the content of the promising being immoral, wil1 be addressed below).

Reinach holds that the obligation of the promise is itself extra-moral, but that a moral duty is created by the act of promising in that it is morally right to keep one's promises. The moral duty here presupposes the obligation created by the promising. Even though the moral duty is inseparable from the promising, the moral duty "...has to be distinguished as sharply as possible from the obligation." 40

It seems, however, that Reinach is making the analysis more complicated than it needs to be, especially because the idea of an obligation which is not itse $1 \mathrm{f}$ moral is a strange one. 41 In the example of the person who promises to stop abusing alcohol, Reinach would have to hold that the promisor now has three duties: the moral duty to refrain from the abuse, the duty to refrain from the abuse the sole ground of which is the act of promising, and the moral duty to refrain from the abuse the ground of which duty is the duty 
created by the promising.

It seems rather that the promisor in this case has on $1 \mathrm{y}$ two duties, both of which are moral: the moral duty to refrain from the abuse, the ground of which is a moral1y right state of affairs, and the moral duty to refrain from the abuse the sole ground of which is the act of promising.

Next, in pointing out the fact that promising and expressing an intention can make use of the same linguistic expressions, Reinach mentions that the following misunderstanding is possible: A person can mistakenly think that a promise has been made to him when in reality all that had been done was that an intention had been expressed. It is important here to realize that the person thought to be the promisor cannot have intentionally led the other to believe that he was making a promise when he actually never meant to fulfill the promise. Otherwise what would occur would be what Reinach refers to as a 'pseudo-promise'. In making a pseudo-promise, one turns to another and expresses oneself just as one would in making a sincere promise; however, one only pretends to be promising authentically without a sincere intention of doing the thing promised. 42

An interesting question that arises is whether the person thought to be the promisor has an obligation to rectify the erroneous belief. With the first case, in which the one thought to be the promisor did not intentionally deceive the other person, it must first of a 11 be assumed that the 'promisor' is aware of the mistaken belief. Then the answer to this question depends on whether the person thought to be the promisor is at fault for the mistaken 
impression that he has given. If he is not at fault at a11, no obligation seems to be present. If he is part $1 y$ or most $1 y$ at fault because of ambiguous language or other carelessness, and the mistaken belief is easy to be dispelled, then it seems that he would have an obligation to do so. This obligation seems to be different from the one that would arise from a true act of promising. 43 If a person has given the impression that he has made a promise and it is most $1 \mathrm{y}$ his fault, yet he does not attempt to rectify the mistaken belief, this is still different from a pseudopromise, because the person has not pretended to promise but rather omitted an action, the act of informing that no promise has been made. In the case of a person who makes a pseudo-promise, it is clear that there is an obligation to correct the deception, and this obligation does not depend on whether it can be easily dispelled or not.

A further question is whether a claim and an obligation come into existence concerning the content of the expressed intention or the pseudo-promise in any of the above situations. With the situation in which it was not the 'promisor's' fault at a11 that a misunderstanding occurred, there would clearly be no obligation to fulfill the content of the expressed intention, with the exception of the case in which a person would suffer harm otherwise, as explained above.

On the other hand, if it was partly or mostly his fault, and if he does nothing to dispel the mistaken belief even though he is aware of it, then perhaps he would have an obligation to fulfill the 
content of the action, especially if harm would come to the 'promisee', but even, it seems, if no serious harm would be caused. This obligation, again, is distinct from the obligation that arises from an actual act of promising. As far as making of a pseudopromise is concerned, it might be that a claim and obligation come into existence just as if the person would have made a sincere promise. 44

Another question that arises stems from Reinach's belief that one possible way for a promise to be dissolved is for the promisor to revoke the promise. Although he emphasizes later that a revoking can occur on $1 \mathrm{y}$ with the permission of the promisee, 45 it doesn't seem that a revoking occurs at a11. It seems rather that what happens is merely a waiving, it is just that the promisor has requested the promisee to waive the latter's claim. ${ }^{46}$ The fact that the promisee might not otherwise waive his claim does not seem to thereby warrant the use of the term 'revoke'.

Besides the content of the promise being fulfilled, the promisee waiving his claim, or the promisor revoking the promise, Reinach speaks of another 'end' that might come to a promise: an obligation can become impossible to fulfil1. He mentions two ways in which this could occur. First, the promisor might become unable to fulfill his obligation, and second, something might happen that makes it impossible for the promisor to fulfill his obligation through any action. Reinach then states that if it does happen that the obligation becomes impossible to fulfill, the claim and obligation do not thereby dissolve but the obligatory relationship does take on a peculiar kind of meaninglessness; "Claim 
and obligation have become incurably sick." 47

Later, Reinach mentions a situation in which an obligation from an act of promising the content of which is immoral is outweighed by a higher duty to act moral1y. ${ }^{48}$ This situation is different from the two above mentioned possibilities; it cannot really be said that the content is impossible to fulfill just because it is immora1. There are two points that must here be addressed. First of a11, are there any other possible ways for a promise to 'meet an end' other then the above ways mentioned by Reinach? (The term 'meet an end' is here intentionally vague.) Second $1 \mathrm{y}$, is it rea11y true that the obligation does not cease to exist even though it becomes impossible to fulfil1?

To start with the first question, it will be helpful to consider some examples 49 that would be included under the ways for a promise to come to an end that were mentioned by Reinach. The first way was that the promisor for some reason becomes unable to fulfill his obligation. This must mean that he has somehow lost an ability necessary for the fulfilling of the obligation. For example, a person promises his friend that he will look at his paintings, but before he can do so he becomes blind or goes into a coma. Or the promisor suffers a certain degree of loss of rationality, for example becoming senile or getting Alzheimer's Disease. Also included in this group of situations would be the death of the promisor. (An exception to this last example must be made if the promise is such that it has a particular condition. The topic of promises that have a condition will be addressed below.) 
The second way for a promise to 'come to an end' can be that something occurs in the world, rather than to the promisor which makes it impossible for him to fulfill his obligation. If a person promises someone to take him or her sailing, and before he can do so the promisee dies, clearly this prevents the obligation from being fulfilled. (An exception to this will be addressed under the topic of promises that have a condition.) Another example could be that a person promises his brother that he will wash his car and before he can do so, the car is towed away and demolished.

Final1y, an example of the last way for a promise to come to an end that was mentioned by Reinach could be that a person promises to steal a pack of gum. As mentioned above, Reinach would hold that the obligation to steal the gum would be superceded by the higher duty to act mora11y.

An affirmative answer can be given to the question of whether there is another way for a promise to 'come to an end'. A promise can be superceded by a higher duty, even if the content of the promise is not immora 1.50 Take the example of a person making a promise to bring someone out to dinner at a particular time. On the way to dinner, the promisor comes across a person who has had an accident and needs 'CPR'. It so happens that the promisor knows 'CPR' and with no harm to himself could easily save the accident victim. To let the person die because he wishes to keep his promise would clearly be wrong.

To answer the second question of whether or not an obligation ceases to exist even though it becomes impossible to fulfill, it will be helpful to determine which cases are those in 
which the promise clearly ceases to exist, and which are those in which the promise becomes impossible to fulfill. It is clear that the promise ceases to exist if the obligation is fulfilled or the promisee waives his claim. (Revoking will not here be addressed because of the problems with revoking that were mentioned ear1ier.) Reinach holds that the promise becomes impossible to fulfill but does not thereby dissolve if the promisor becomes unable to fulfill the obligation or if an 'external' situation arises which prevents the promisor from fulfilling the obligation through any action. 51 Is this true? To take the first example of the promisor being unable to fulfill the obligation, namely that the promisor has died, it is clear that the obligation no longer exists. If there is no obligation then how can the promisee have a claim? The dissolution of the obligation has broken the obligatory relationship, therefore the promise ceases to exist. If on the other hand the promisor loses the ability to fulfil1 the ob1igation because of blindness, for example, the situation is a bit more complex. Take the example of the person who promises a friend to look at the friend's paintings but before he can do so he goes blind. Does the promise cease to exist? What if the blindness is on ly temporary and to the surprise of everyone the promisor regains his vision? Is he then obligated to look at the paintings, or has his obigation been dissolved? One thing is certain, and that is that the same obligation cannot pop in and out of existence. The on $1 \mathrm{y}$ way that the person can be obligated to look at the paintings after regaining his vision is if the obligation 
never ceased to exist in the first place.

This does seem to be the way to analyze the situation, that

is, that the promisor does have an obligation once his sight

returns. It must be then that while he is blind the obligation is

suspended, so to speak. Of course if content of the promise included

a time reference, for example if the person had promised to look at

the paintings the next day but he becomes blind the day the promise

was made and does not regain his sight for a week, then the

obligation has dissolved and with it the promise. On the other hand

if the promisor became permanent $1 \mathrm{y}$ blind then it seems that the

obligation would dissolve and thus the promise would cease to exist.

Further, the existence of the obligation is not dependent on the promisor's and/or promisee's awareness of it. In the example of the promisor becoming permanent $1 \mathrm{y}$ blind, the obligation is dissolved even if everyone believed him to be only temporarily blinded. In the example of the promisor being only temporarily blinded, he retains his obligation even if everyone believes him to be permanent $1 \mathrm{y}$ blinded. In this latter case, the obligation is suspended and so of course he is not held responsible for an action that he cannot perform. So whereas under Reinach's analys is the situation of permanent blindness would result in the obligatory relationship becoming 'incurably sick' but nonetheless stil1 existing, it seems that the correct analysis is rather that if the obligation truly becomes impossible to fulfil1, then it dissolves and thus the promise ceases to exist altogether.

With the example of the promisor suffering a loss of rationality due to senility or Alzheimer's disease, it might be that 
the promisor loses the degree of rationality necessary to fulfill the obligation entirely, or that the loss of an adequate degree of rationality occurs on ly periodically, that the person 'goes in and out' of rationality. In either case the analysis would be parallel to that given for the situation in which the promisor became blind. With the death of the promisee, the claim has ceased to exist. Thus, the claim-obligation relationship is destroyed, and so the promise ceases to exist. (There is a possible exception to this when it comes to promises that have conditions. This will be discussed below.)

The next example is of a promise to wash a car, when the car is subsequent $1 \mathrm{y}$ towed and demolished. Whether or not the promisor was precise in the wording of the promise makes a difference here. If he said, "I promise to wash your car" and gives neither a reference to a specific vehicle nor a time reference, it seems that the obligation remains suspended until the promisee buys a new car, at which time the promisor is again responsible for fulfilling the obligation. If the promisor refers to a specific car which is then towed and demolished, however, the obligation has become truly impossible to fulfill and the promisor is no longer obligated. The obligatory relationship is destroyed and therefore the promise ceases to exist.

The next situation is that in which the content of the promise is immoral and therefore the obligation to fulfill it is superseded by a higher duty to act mora11y. Reinach does not address the question of whether this leads to the dissolution of the promise 
or not. And as mentioned above it does not seem accurate to say of the obligation that it is impossible to fulfill just because it is immoral. But perhaps Reinach is missing something here. Perhaps it makes a difference whether or not the promisor is aware of the immorality of the content of the promise, and whether or not the content is intrinsically immoral or only immoral due to external circumstances. In the case in which the content is on $1 y$ immoral due to external circumstances, the content can become immoral where before it was not. For example, a person promises a friend that he will buy him a beer at the bar where they plan to meet that night. When the promisor gets to the bar, he finds that his friend has been drinking for a while, and that to buy him a beer now would clearly be detrimenta1. Obvious1y, buying a beer for a friend is not intrinsica11y immora1. In this situation, however, it would be wrong to fulfill the content of the promise, because it has become immoral due to external circumstances, that is, the fact that the friend has already had too much to drink.

On the other hand, if the content of the promise is immoral from the start, either intrinsical1y or due to external circumstances, then perhaps no promise comes into existence from the beginning. This would be the case if it is true that a condition for a promise to come into being at al1 is missing, namely that the content not be immora1. 52

Reinach would strongly disagree with this view, because he holds that the obligation is grounded in the nature of promising as an act and not in its content; the immorality of the content can, therefore, in no way touch this essential 1aw.53 
With the situation in which a promise is made and neither the promisor nor promisee are aware of the immorality of the content, it does not seem that what occurs is that a promise comes into existence, but the obligation is superseded by a higher duty to act moral1y. If a condition for a promise to come into existence is that the content not be immoral, then it seems that the fact that one or both of the partners are not aware of the immorality (or even of this condition) has no bearing on the issue, and that the promise would not come into existence even if they thought it had.

If it is true that the content of the promise is not intrinsical1y immoral but it on $1 \mathrm{y}$ becomes wrong to fulfill due to external circumstances after the promise has been made, then this is an entirely different matter. In this case the promisor has not violated the above condition for a promise to come into existence because the content was not immoral at the time the promise was made. And so the promise does come into existence, but the obligation to fulfill it is superseded by the higher duty to do what is right.

Does the outweighed obligation still exist? Is it true that in this case rather than being dissolved the obligation takes on a kind of meaninglessness, becomes 'incurably sick?' There are two possibilities. Since the content is on $1 \mathrm{y}$ immoral due to externa 1 circumstances, it is plausible that these circumstances could change in such a way that the content is no longer immoral to fulfill. It seems that if this is the case then the obligation is merely suspended, and when the time comes that it can be fulfilled without 
violating the higher duty to act moral1y, the promisor will again be responsible for fulfilling that obligation. The on $1 y$ way for this to occur, again, is if the obligation never ceased to exist from the start. It might be that during the time in which the obligation is suspended the obligatory relationship can be referred to as having taken on a sort of meaninglessness. If though, the circumstances never change in such a way so as to make the content no longer immoral. then it seems that the obligatory relationship would remain in this state of 'meaninglessness'. It does not seem that there is any reason to believe that the promise would cease to exist.

Finally, the last case is that in which the content of the promise is not immoral, but the obligation to fulfill it is superseded nonetheless. The example given for this situation was that of a person who makes a promise to take someone out to dinner but on his way to dinner comes across a person whose 1 ife is in danger and whom he could easily save. The duty to take the promisee out to dinner is superseded by the duty to save the other's 1ife.

Does the obligation created by the act of promising still exist in this situation, or does it take on the state of 'meaninglessness' referred to above? The on $1 \mathrm{y}$ way that the obligation to fulfill the promise is superseded is if it is impossible to do both, that is, save the life and keep the promise. Otherwise there is no question of superseding. Thus, if the obligation created by the act of promising is impossible to fulfill. then the promisor cannot be obligated to fulfill it. The obligatory relationship is destroyed and so the promise ceases to exist.

There is another situation which must be addressed. It could 
happen that a promise does not actual1y become impossible to fulfil1, but that the situation changes from the time the promise is made so that it becomes very difficult to fulfill the promise, much more difficult then it was at the time the promise was made. 54 For example, a person promises his son that he will buy him a model airplane that they have seen in a particular store. When the man goes to buy it the next day, he finds that al1 of them have been. sold out and will not be reordered. He cannot have it ordered from another store, but he can drive twelve hours to another state to buy it. Since the situation has changed from the time the promise was made, however, so as to make it very difficult for the promisor to fulfill his obligation, it seems that the obligation has been dissolved. In other words, unless a clause is explicitly added to the promise to the effect that the obligation becoming extremely difficult to fulfill will not dissolve the promise, such as "I promise that no matter how long it takes me or how difficult it is. I will buy you that model airplane", then it seems that the promise would dissolve. Thus it appears that another way for a promise to meet an end is for the promise to become unusually difficult, or a hardship, to fulfil1, at some time after the promise has been made. In this case it seems that the obligation is dissolved and thus the promise ceases to exist. If it will be a hardship to perform an action even before the promise is made and neither party realize it, then it seems that the obligation does not come into existence from the beginning. 
It was mentioned above that there were two exceptions to the promise ceasing to exist at the death of the promisee or promisor. This brings up the topic of promises that have a condition. Reinach sharply distinguishes between promises that have conditions but are themselves unconditional and conditional promises. With the former type of promise, he explains that claim and obligation come into being immediately. The promisee can waive the claim before the condition is fulfilled. With a conditional promise, however, the claim and obligation come into being only on the fulfillment of the condition. There is nothing at the outset that could be waived. 55 It seems that with a promise that has a condition, claim and obligation come into existence with the making of the promise, but they are 'suspended', so to speak, and are on $1 y$ actualized with the fulfillment of the condition.

With conditional promising, Reinach explains that this type of promising,

is not exactly without any immediate efficacy at a11. It creates in the promisor a state of being bound which shows itself in the fact that he can no longer avoid acquiring an obligation when the condition is fulfilled." 56

Unfortunately, Reinach does not provide an example of what he means by conditional promising, but the difference between no longer being able to avoid acquiring an obligation once the condition is fulfilled, and having to fullfill a previously suspended obligation once the condition is fulfilled, seem to be close enough to make one wonder why the concept of 'conditional promising' is even necessary. Because of this, only promises that have conditions will here be analyzed, and not 'conditional promises'. 
A common type of condition that a promise can have is a time 1imit, so to speak. For example, a person says to a friend, "I promise to take you out to dinner before school starts next week." If the promisee then keeps cancelling a11 of the proposed times to have dinner and the promise is not fulfilled before school starts the next week, the claim will have dissolved. The promise then, is no longer in existence.

The situation would have to be viewed different $1 \mathrm{y}$ if it was the promisor who kept cancelling the dinner dates. In this case, if he has not taken his friend out to dinner before school started, then he will have broken the promise, meaning that it can no longer be fulfilled. The obligation has ceased and thus the promise no longer exists.

A time limit is not the on $1 y$ condition that a promise can have. For example, one can say, "I promise to take you for a ride this afternoon, as 1 ong as it is not raining then." There are rea11y two conditions here, because if it is raining in the afternoon, even if it clears up by evening, there is no longer an obligation, and thus the promise has ceased to exist. There does not seem to be a limit to the amount of conditions which a particular promise can have. As seen by the above examples, then, a promise that has one or more conditions ceases to exist if the conditions are not met and cannot be met in the future.

A different situation would occur if the condition of the promise were the death of the promisor. Suppose that a person says, "I promise that if I die before you do, you will get my house." 
Peculiar to this type of promise is the fact that the promisor has an actualized obligation before the condition is met, for obvious $1 y$ he must make provisions before he dies so that the house will be left to the promisee. The claim, however, is suspended until the condition is fulfilled. At the death of the promisor, the claim becomes actualized, but the obligation will have been already fulfilled. Or maybe it is that the obligation is really transferred to whoever it is that is responsible for taking care of the promisor's wishes after he dies.

Much more complicated is the situation which occurs if a promise has as a condition the death of the promisee. One can say, for example, "I promise that if you die before me I will keep up your garden." In this situation, the fulfillment of the condition is the death of the bearer of the claim. According to Reinach, claim and obligation must have a bearer. If the bearer dies, it would seem that as in the other cases, the claim ceases to exist. Otherwise, who would hold the claim? And since, as said above, the promise is a claim-obligation relationship, with the dissolution of the claim. that relationship is destroyed.

That the obligation that arises from promising is totally dependent upon the claim of the promisee is also obvious in that waiving of the claim leads to the dissolution of the obligation. And so if the condition of the promise is the death of the promisee, when the condition is fulfilled, the obligation changes from being in a state of suspension to being actualized, but the fulfillment of this particular condition is the very thing which destroys the obligation. It would appear that to make such a promise 
would from the start be nonsensical. 57

Another type of promise is one in which the addressee of the content of the obligation is a person other than the promisee. Reinach explains,

The obligation to do something for someone is different from the obligation to someone to do something. So we distinguish between the addressee of the content of the obligation, and the addressee of the obligation itse 1 f. 58

In other words, the action, or omission of an action, that will

fulfill the obligation is directed not to the bearer of the claim, but to a third person. For example, A promises B to pay C $\$ 100.00$. Reinach states that in this example, B need not cease to be the bearer of the claim. 59 In fact, it does not seem possible that C could be the bearer of the claim if the promise is made to $B$. That $C$ in no way holds the claim is obvious since $C$ may not even be aware of the promise, and need not be.

Furthermore, Reinach had said that a claim can on $1 \mathrm{y}$ arise for the person to whom the promise is addressed; "It is apriori impossible that a person to whom the promise is not directed should acquire a claim from it." 60

To analyse this type of promise in the same manner as the previous examples, it should be clear that once $A$ has paid the $\$ 100.00$ to $C$, the promise is fulfilled and thus ceases to exist. If it happened that the promisee died before the promise was fulfilled, then the promise would cease to exist since the claim is no longer in existence, and the fact that there is a third party involved does not seem to change this. 
The promise would cease to exist unless, however, there are two obligations. It is unclear whether this was implied by Reinach when he said that a distinction must be made between the obligation to someone to do something, and the obligation to do something for someone. If there are two obligations in the case where a third party is involved, it seems that the obligation which one would have to the third party is dependent upon the obligation which one has to the promisee. With the death of the promisee, then, the claim ceases to exist, so there is no obligation and therefore there can not be an obligation to fulfill the content of the obligation.

A promise that has a condition can be of the above type, that is, it can involve a third party. For example, one can say, "I promise you that I wil1 give Sara $\$ 100.00$ if it rains tomorrow." If it does not rain the next day, or if the promisee dies, then in either case the promisor is no longer obligated to give Sara $\$ 100.00$, because the promise has ceased to exist.

Fina11y, consider the situation of a promise involving a third party that has as a condition the death of the promisee. For example a person says, "I promise to take care of your children if you die before I do." As in the previous examples, the death of the promisee is the dissolution of the claim, and so the problem of how the promisor can be obligated without a corresponding claim remains. Perhaps when the condition of a promise is the death of the promisee, the claim is transferred to the third party. In fact, it seems that this is the only way that such a promise would be meaning ful. 
Another interesting question that arises is whether an intention must be of a certain kind in order to b.e presupposed by an act of promising. Can absolutely any act of intending be the basis for promising? First of a11, in order to intend to do something rather than simply wish to do it, the action in question must be at least possible to accomplish. As Gwennyth Taylor explains, "I may on $1 \mathrm{y}$ want or intend what I can do, and I can on $1 \mathrm{y}$ do or have or bring about what is in some sense within my power, within the sphere of my influence." 61 Take the 'intention' of someone to lift the Eiffel Tower with his bare hands. The on $1 \mathrm{y}$ way that this can even be an intention is if the person is deluded as to the weight and size of the Eiffel Tower, or if one is under a delusion as to one's own strength.

On the other hand, with regard to any intention which an agent has that somehow involves the external world, one never has complete or ultimate control over whether or not the intended action can be fulfilled. There are, however, degrees of control which a person may have over different actions. ${ }^{62}$ So the question becomes: must there be a higher degree of control over an intended action that forms the basis of promising than the degree of control necessary for something to be an intention at a11?

Take the intention to do something over which one does have an influence, but certainly not ultimate control. For example, a student wants to get straight $A^{\prime} s$. He can intend to do this, but this intention cannot be the basis of promising because one does not have enough control over the outcome. Even assuming that one 
has the ability to get straight A's, other possibly unforeseen factors, such as sickness, can nonetheless prevent a person from accomplishing this. A person could only promise to get the best grades that he could under whatever circumstances exist at the time, and under those which may arise in the future.

Another example is that of a person intending to wash a friend's car. It is true that one does not have complete control over this action. Something could happen to prevent one from fulfilling this intention. The car could be stolen, or towed away to a junkyard and crushed. The likelihood of these things happening is not very high, however; there is here more control than one would have over getting straight A's. Thus the intention to wash someone's car can form the basis of an act of promising.

Promising someone to do something which one knows that one cannot do would be a pseudo-promise under Reinach's definition. because one cannnot intend to do something which one knows one cannot do. It can, of course, happen that someone is under the impression that he or she can do something when in actuality this is not possible. It may be that there is a responsibility to find out as far as possible whether one does have the ability and whether the circumstances will allow the carrying out of the content of the promise, before the promise is made. It might also happen that one does have the ability to fulfill the obligation created by the promising, but that the circumstances change in such a way as to make this impossible, as explained above.

At any rate there must be an adequate degree of control over the intended action which forms the basis of promising, and as the 
examples have shown, this degree of control must be higher than the degree necessary for an intention to be present at a11.

Another question is: Must the intended act be at least potentially of interest to another perosn in order for the intention to be the basis of an act of promising? As an example, suppose that a person intends to do something which no one else could possibly care about, for example, a person who lives alone decides to rearrange his sock drawer. Could he make a promise to someone to do this? Although it would be strange to make a promise which is of no interest to someone, it does not seem at first that this would make the act of promising invalid, where invalidity is understood as preventing the promise from coming into existence. An explanation for this might be given in the following way: Could it not happen that, even though a person does not really care whether or not his friend's sock drawer is rearranged, if he is promised that it will be arranged, and then it is not, he would feel that his claim was violated?

The feelings involved with the promise are basica11y irrelevant, however, since the bond formed by promising is objective and therefore exists outside the realm of feelings, desires, etc. Reinach explains that "Nothing is more certain than that I can very well feel myself to be obliged without there real1y being any obligation, and that on the other hand I can very we 11 have a claim without feeling myself to be entitled at the moment in which I have it." 63 So the question must always be whether or not the person's feeling or belief points to an actual claim. 
A second response could be that a promise does come into existence even if the content is of no interest to the addressee, because the content could become of interest to him. For example, an old man promises his young grandson that when the boy becomes a man he will buy him a house. The child understands what his grandfather has said, but does not really care. When the boy has become a man he remembers his grandfather's promise, which is now of great interest to him. Is it not clear that the man has a claim and the grandfather an obligation?

The fact that something is of interest to a person, however, does not mean that that person thereby has a claim. A person can very well feel himself to have a claim when he really does not. There would only be a claim if the promise came into existence at the time when the addressee was not interested in it. Either a promise exists from the very beginning, when the promisor utters the binding statement, or the promise does not exist at a11. So the question remains, can a promise come into existence at a 11 if it is of no interest to the addressee?

It does seem strange that a person can have a claim for something which in no way interests him. John Searle states that a promise is defective if the thing promised is not something the hearer wants done or considers to be in his interests, or would prefer having done to not having done. ${ }^{64}$ A defective promise, however, is nonethless a promise. On the other hand. Gwennyth Taylor seems to hold that for a promise to come into existence, the person to whom the promising is addressed must be interested in the content of the promising. She gives the following example to show how an 
utter lack of interest renders the promising unintelligible:

For consider again the case of promising and imagine a promise such as the following: I promise to bring you the highest leaf from the topmost branch of the first elm I see on my way home. Suppose neither party is a botanist, conservationist or child; and there is no ascertainable point to the offer/acceptance. For what relevent actions ensuing from that promise could I be held responsible? 65

She continues: "Suppose the following day I say 'Look, I didn't get that leaf, but I've brought a pebble instead, and since they are equivalent I have kept my promise, haven't I' How could one know whether the promise had been kept?"66

It appears, then, that for a promise to come into existence the content of the act of promising must be of interest to the addressee. It then follows that for an intention to form the basis of an act of promising, its content must be of interest to the addressee. The content of the promising referred to here is equivalent to the intentional object of the promising, and as was mentioned above, the intentional objects of the intending to do $x$, of the intending to promise to do $x$, and of the inner and outer sides of the promising itself al1 coincide or at least are related to each other.

Another situation that could occur is that the content of the act of promising is not in the interests of the addressee, or in other words, it is against his interests. A deception might here be present on the part of the promisor, who may act as if the content is in the interests of the addressee. (This would not be an example of a pseudo-promise, however, because the promisor does intend to fulfill the content of the proposed promise). Can a promise come 
into existence in this situation? The answer depends on whether the content of the act of promising is morally wrong or not. Not all actions which are against the interests of a person are thereby immora1.67 If then, the content of the promising was morally wrong at the time the promise was made, then as explained above, the promise does not come into existence from the beginning. If however the content is not intrinsically wrong but becomes wrong after the promise is made, then this would be a situation in which a higher duty supersedes the duty to fulfill the claim.

If the content is not moral1y wrong, and does not become morally wrong due to external circumstances, then there does not seem to be any reason why the promise would not come into existence. The exception to this would be if the addressee rejects the promising from the start, because in this case the promise would not come into being. ${ }^{68}$ If the addressee does not realize at first that the content is against his interests, then although the promise might come into being, he can always waive his claim.

It is, of course, not even necessary for the content of the promise to be against the interests of the promisee in order for the promisee to be able to waive his claim. The content could at first be of interest to him and later not. At the later time, he can stil1 waive his claim. Or perhaps he simply changes his mind. The promisee can always waive his claim, because there is no obligation to keep a claim. ${ }^{69}$ A problematic situation would occur, however, if the promisee never realizes that the content of the promise is against his interests. Could he actual1y have a claim that harm be done to him? Even worse, what if he promises to accept this claim? 
Does he then have an obligation to accept a claim that would be bad for him?

Tackling the first case, as long as the content is not morally wrong but simply to the disadvantage of the promisee, then the promisee does in fact have a claim that something be done which is against his interests. If he never realizes this and does not opt to waive his claim, then the promisor's obligation to do what is to the promisee's disadvantage is indeed to be fulfilled.

Taking the more complicated case of the promisee himself making a promise to accept the promise made to him, the analysis again depends on whether the content is morally wrong or not. If the content is moral1y wrong, then the situation would be analyzed as explained earlier. If the content is not morally wrong but simply not to the advantage of the original promisee, then it might seem that the original promisee has waived his right to waive his claim by promising not to waive it. Reinach, however, holds that even if one has promised to accept a service,

It is false to say that the claim cannot then be waived, for the ability to waive is grounded immutably in the essence of a claim. But even if the claim is waived there still very much remains, on the basis of the second promise, an obligation in the holder of the origina 1 claim. 70

So it seems that one can never promise not to waive a claim, but on $1 y$ promise to accept the content of a promise. If one waives the claim, then the original promisor no longer has an obligation. One would, however, have an obligation to accept the original promise as long as the original promisor does not waive his claim that his promise be accepted. Thus it is possible to have an 
obligation to accept a claim that is to one's disadvantage. Perhaps this is truly a case in which the promise can be said to be 'defective'. 
CHAPTER FIVE: AN ANALYSIS OF THE MAKING OF A MARRIAGE VOW AND THE VOW AS COMPARED AND CONTRASTED WITH PROMISING AND THE PROMISE

On the basis of the analysis of promising and the promise, an analysis of vowing and the vow will now be attempted. The act of making a vow, like the making of a promise, results in a claim and obligation, and thus brings a bond into existence. Because of this, the vow is a type of commitment. The bond is objective in the same sense that the bond created by the act of promising is objective. What must be examined are the ways in which the vow is similar to the promise and different from it. There are times when the words "promise" and "vow" are used interchangeab1y, as when the vow taken in marriage is referred to as the "marriage promise". (This usage is present in the article entitled "Marital Fidelity" by Susan Mendus, which will be referred to below.) In fact in the taking of marriage vows, each person is normally asked whether they promise to "love honor and obey", and the vow has been defined as a "solemn promise...an act by which one consecrates or devotes himself to some act, service or condition...a solemn assertion..."71

As will be shown below, however, what Reinach has held to be characteristic of promises does not always hold true of vows, and so either the above usages are not very precise in treating vows as if they were a type of promise, or Reinach has failed to take into 
account a specific type of promise which does not share al1 of the characteristics that the other types of promises have. Much depends, of course, on whether the differences between vows and promises are essential or not. An essential difference between the two would require the use of a different name for each.

The answer to this question should be clear after an analysis has been made regarding the essential nature of the vow. Let it be clear from the beginning, however, that on $1 y$ those acts by which a person binds himself to something outside of himself, creating an extra-mentally existing bond, will be considered. This wil1 rule out simple declarations and assertions which are at times loose1y referred to as vows.

What complicates matters is the fact that there are different types of vows, for example a marriage vow, religious vows, and a vow to change a certain behavior, to name a few. To simplify matters, a particular type of vow, the vow taken in marriage, will be compared and contrasted with the promise. No claim will be made that what holds true of the marriage vow also holds true of these other types of vows, and from here on whenever the term vow is used it should be assumed that what is meant is the marriage vow.

The vow, which is the product, so to speak, of the vowing, or making of the vow, seems to be nothing more than the bond which the act of vowing brings into existence. Because of this, the vow will at times be referred to simply as 'the bond', and of course it should be understood that if the term vow is used, it refers to the bond. 
existence, and as mentioned above the existence of the claim and obligation is an objective one, the act of vowing must be more than simply an expression of intention. This follows for the same reasons that the act of promising must be more than simply an expression of intention to account for the existence of an objectively existing claim and obligation; namely, that an expression of intention does not bring an objective bond into existence.

What then is the nature of the act of vowing? First of all. the marriage vow is not only an intentional act but is a1so a spontaneous act. It belongs to that particular type of spontaneous act which was called by Reinach the "social act," because it is not only other-directed, it also addresses the other and so must be externa11y expressed. Unique to the marriage vow is the element of reciprocity, which is a requirement for the marriage vow to even come into existence at a11.

The making of a marriage vow presupposes two internally complete experiences. One of the experiences is an intention to make a marriage vow, and this intention itself presupposes a further experience which is an intention to live up to a specific content. This content will coincide with the content of the intention to make a marriage vow, and with the content of the marriage vow itself, if it is made.

The act of making a marriage vow itself consists of an inner experience which must exist in unity with an external expression of this experience. The inner experience, which can be referred to as the inner side of the act of making a vow, must be more than a mere intention. It is rather the vowing itself, the binding of oneself to 
the other. It is from this creative act that an efficacy proceeds; claim and obligation come into existence.

The expression of the vow, as the expression of the promise, is completely subject to our voluntariness. Furthermore, both persons must be making the vow free of coersion. It seems that this requirement would be satisfied if the vow indeed presupposes an intention to make the vow and an intention to live up to the content of the vow.

Like the other social acts, the act of vowing can on $1 \mathrm{y}$ be directed to the person to whom it is being made. A particular act of vowing can meaningful1y be performed on $1 \mathrm{y}$ once and thus can on $1 \mathrm{y}$ be made in the present tense. It is true that at times a renewal of marriage vows take place. This renewa 1 , however, is not an actual vowing, but is rather a reminder of the commitment which the spouses have already made to one another. (It can also be further meaningful if a promise is made as part of the renewal to try to live up to the vow more perfect1y.)

Just as with promising, the making of a marriage vow is not morally obligatory. Once one has made a vow, however, one has a moral obligation.

Like the claim and obligation which arise from the act of promising, the claim and obligation which arise from the making of a vow are not mental entities, and neither can they be reduced to mere feelings of being obliged or entitled. Just as a pseudo-promise, it seems possible that a pseudo-vow can also be made. Although the person who makes the pseudo-vow might have an obligation as a result 
of it, it does not seem to follow that the partner would thereby have any obligation, especially once the deception is revealed.

Both the claim and obligation which come into existence from the act of making a vow are temporal in that they come into being at a specific time and refer to a future action, or more precisely, to a set of actions.

Like the promise, the vow too can exist for years without change. On the other hand, promises were said to have an inherent tendency toward meeting an end and that this would most commonly occur if the promise is fulfilled or the claim is waived. Here are perhaps the two most significant differences between the marriage vow and the promise. First of a11, it cannot be said in any way that a marriage vow has an inherent tendency toward being dissolved. It is of the very nature of the vow to last "till death do us part". It might be, of course, that the vow can meet an end in some way. This leads to the second significant difference between the marriage vow and promise, namely that the marriage vow does not meet an end by being fulfilled. In fact the term fulfilled has been purposely avoided in speaking of the marriage vow because it is so much more accurate to speak of "living up to" a vow. A vow can be lived up to more or less perfectly, but even if it were possible for a person to perfectly live up to the marriage vow, on a particular day perhaps, the vow clearly would still not then meet an end.

An obvious question is: Although a vow does not meet an end by being fulfilled, can it meet an end by being waived? Since each spouse has a claim and an obligation, it seems apparent that if only one spouse waived his or her claim this would not affect the claim 
of the other spouse. It does seem possible, however, that both spouses could each waive their own claims, and 1 imiting the discussion to natural reason, it seems that this would mean the dissolution of the bond. 72

The vow shares with the promise the fact that the claim and obligation of each presuppose a bearer, and the bearer in each case must be a person. A1so, the claim and obligation must have a definite content to which they refer, and they must have an identica1 content. With a promise, however, one can have an obligation that something take place through another, but this does not seem to be at a11 possible when it comes to the obligation that arises from the making of the marriage vow.

Secondly, three types of obligations arising from promising were distinguished, namely, an obligation which aims at an action, one which aims through an action at an end result, and one in which both means and end are determined. With the marriage vow, however, it does not seem that a means to an end would ever be determined. and even less that both means and end would be determined. 
CHAPTER SIX: QUESTIONS THAT ARISE ON THE BASIS OF THE ABOVE ANALYSIS

It was said that a certain degree of control was necessary in order for an action to form the content of a promise. It seems that a certain degree of control over an action to form the content of marriage vow is also necessary. An important question to consider, then, is the following: what exactly is the content of the marriage vow? This question is not as straightforward as it may at first seem. One answer is that since the couple normally vows to "love, honor and obey till death", that loving, honoring and obeying til1 death must then be the content. Can a person have an adequate degree of control over loving, honoring and obeying for these to form the content of a vow?

A vow to obey, first of a11, is nonsensical unless on $1 y$ one of the person takes this vow. After a11, if they each vow to obey the other, what happens when they disagree? There is no reason why the command of one spouse would hold any more or less weight than the opposite command of the other. The question of why one spouse would be required to take a vow to obey while the other does not is one which goes beyond the scope of this paper, and perhaps also beyond the realm of natural reason. Because of this, obedience will be ruled out as forming part of the content of the marriage vow. A vow to honor is actually less problematic than the vow to 
obey. It seems that one does have control over whether one honors one's spouse or not. One might object to this by pointing out that one's spouse could change in such a way as to be no longer deserving of honor, and one does not exercise much control over this. It seems that honor is to be understood in a different way than this, however, and that the meaning is closer to that of reverence or respect. If it is assumed that all persons have an intrinsic value, then all persons would always be worthy of reverence. It follows then that a response of reverence is due to al1 persons, including one's spouse. On the other hand, if a response of reverence toward a11 persons is an obligation, then the vow to have reverence toward one's spouse seems to be a bit less significant.

Most problematic is the vow to love. What degree of control, if any, can one have over loving? Susan Mendus, in her article entitled "Marital Faithfulness," explains that "...the most familiar objection to the marriage promise (is that) it is a promise about feelings, where these are not under the direct control of the wi11."73 (Mendus herself does not address this objection.) Is it accurate to claim that the marriage vow is a vow about feelings? Can feelings be under the direct control of the will, and if so is the degree of control adequate enough for the feelings to form the basis of an act of vowing? The answer to the first of these questions depends upon the answer to another question, namely, what is the nature of love? Is it a mere feeling, or an act of the will, or perhaps some combination of these two elemants? In the book, "The Art of Living" by Dietrich and Alice Von Hildebrand, it is explained that many philosophers traditional1y have insisted that loving is an 
act of the will because they wish to save its spirituality, ${ }^{74}$ and perhaps also because they wish to give it a position of honor, holding it to be somehow above the realm of mere instincts, physical feelings, and fleeting emotions. The term "spiritual" is here a technical term used by the Von Hildebrands in a meaning which does not coincide with any of the everyday connotations of the term. Its meaning should become clear after several marks of the spiritual character of an experience are mentioned below.

The definition of love as an act of the will does not seem to be in line with the experience of love in a rea1, concrete situation. If the person I love "...on 1y wills to love me, I am quite right in thinking this is a poor substitute; I realize that he has not given me his true self...". 75

Moreover, love is experienced as having a warmth, a plenitude and a depth which is not present in a "naked" act of willing. 76 Thus, according to the Von Hildebrands, love must not be a mere act of the will but must rather be an affective response. This does not mean, however, that love is not spiritual. 77 To see that this is true, it is first necessary to understand that there are two essential1y different types of affectivity: the lower, nonspiritual affective experience, like for example a state of depression and the higher, spiritual affective response, of which joy is an example. That joy is a spiritual type of response is evident, first of all, by the fact that it consists of an intentional relation to an object or event. 78 The term "intentional" is a technical term the meaning of which does not coinicide with the 
common meaning of "on purpose". It rather denotes a type of experience that presupposes an object. That is, in experiencing joy a person has a conscious, meaningful, intelligible relation to a particular object or event which is the source of the joy, or more precisely, joy involves a response to the object. This intentionality is the first presupposition for the spirituality of a human experience. 79 The affective value response of joy also involves a transcendence of the self to the object of the joy, and this transcendence is a second fundamental mark of spirituality. And a third mark of the spiritual character of this joy discloses itse $1 \mathrm{f}$ in the fact that we need not have formerly experienced that something engenders joy in order to grasp that it can engender joy. ${ }^{80}$ For example, if a person has never before experienced spousal love, and a friend who is getting married explains to him the nature of this love, the first person can grasp the fact that spousal love can be the source of deep joy.

Fina11y, "...affective value responses, for example a value responding joy, a love, a veneration, presuppose the body not a whit more than an act of wil1..."81 Love belongs to this higher, spiritual type of affectivity, the affective value response. Like joy, which is referred to in the "Art of Living" as both an experience and a response, ${ }^{82}$ 1ove, too, is both an experience and a response. So in answer to the enquiry of whether the marriage vow is a vow about feelings, the response appears to be affirmative, since it seems obvious that love should be present with the making of a marriage vow, and love, as has been shown, is in fact a feeling. The next question is whether this particular type of feeling can indeed 
form the content of a vow. What degree of control can be exercised over love, or in other words, what role if any does the will have in the act of loving?

As a feeling, love is not under the direct control of the wi11; it is not in itself free. It is rather willing which has the extraordinary feature of being free. 83 The Von Hildebrands explain that even if we wanted to, we could neither engender nor command the response of love. This does not mean, however, that love is completely outside the realm of a person's freedom. First of all, love is within the range of one's indirect power:

By means of our free will we can do many things in order to 1 iberate our heart from the obstacles which hinder it from giving the right response. Similarly, the possession of virtues is not within our direct power. We cannot command them as we can command actions. Yet nobody will deny that we can strive for the possession of a virtue, and that we are responsible for not possessing it. 84

This is not the only way in which the affective value response of love is related to freedom. Love can share in our direct freedom by the fact it can be sanctioned with one's free will. 85 Returning to the objection which holds that the marriage vow is invalid as a vow since it is a vow about feelings which are not under the direct control of the will, we would have to agree, it seems, with both the characterization of love as a feeling, although with the distinctions made above, and with the idea that it is therefore not under the direct control of the wi11. But whether these two points make love invalid as the content of the marriage 
vow is not so clear, since the will is involved, as has been shown, and it seems one can be held responsible for neglecting to overcome the obstacles to love and for not sanctioning love.

Love itself is within the range of one's indirect power, and it is within the range of one's direct power to sanction love. The question is, is this degree of control adequate enough to allow loving to form the content of the marriage vow? After a11, since it is a feeling, it is plausible that love could simply disappear, or be 1ost. It seems, then, that there is not an adequate degree of control over love in order for it to form the content of the marriage vow, because one cannot have direct control over love itself.

On the other hand, it seems that love cannot be separated from a certain giving of self, and a giving of self is under direct control of the will. The giving of self does form part of the content of the marraige vow: "...the two partners give themselves expressly to each other, fully sanctioning this surrender for their entire lifetime." 86 Love is the reason for the giving of self, it is what makes the giving of self desirable. But the giving of self can, it seems, occur in the absence of love. Thus love itself has still not been included as part of the content of the marriage vow. And yet, one vows to 1ove. Perhaps the answer is that only a particular type of love can form the content of the marriage vow. That is, although it seems that spousal love, which by definition is quite intense, 87 cannot form the content of the marriage vow, perhaps a different kind of love can be part of the content. Charitable love seems to be a likely candidate. Charitable love, however, is still 
love and as such seems to involve feelings which are not under the direct control of the wil1. Admittedly, the performance of charitable actions will most likely lead to charitable love, but then on $1 \mathrm{y}$ the performance of charitable actions can form the content of the vow, and not charitable love itself.

It also does not seem that charitable actions themselves can be defined as a type of 1ove. A charitable action, even if defined as an action which is motivated out of concern for the good of another, can be performed with a cold sense of duty instead of with a11 of the warmth and plenitude that is present with love.

Thus far, then, the content of the marriage vow seems to include the removal of obstacles to love, the sanctioning of love as long as it is present, the giving of oneself to the other, the performance of charitable actions, and reverence for the other. The last of these seems closest to a vow to love, but love itself is still not part of the content.

What changes matters is if love is defined as the willing of the other's good, then it can form part of the content of the marriage vow. Willing another's good is different from willing to love someone. And yet it is still an act of willing. What of the warmth, plenitude and depth which seem so inseparable from love? After a11 it does seem true that one can te11 the difference between an act of kindness performed out of love, and one performed out of a cold sense of duty. Perhaps the answer is that if one truly wills the good for another, the warmth, plenitude, and depth so characteristic of love will also be present. But even if at times 
they are not present, the love is not therefore lost. The willing of the other's good is the anchor, so to speak, of the love. The warmth, plenitude, and depth are an extra gift that come with a love that is nearer to perfection, but are not essential to love itself. In the section on promising the issue of promises becoming impossible to fulfill was raised. As already mentioned, it is not accurate to speak of the marriage vow being fulfilled, but on $1 \mathrm{y}$ of it being lived up to to a greater or lesser degree. A question can be raised, however, as to whether it can happen that a marriage vow becomes impossible to live up to at a11. What would happen if one of the spouses became unable to fulfill any of his or her obligations to the other? It seems that the on $1 \mathrm{y}$ way that this could occur is if the person suffered a loss of rationality. If only one spouse suffers a loss of rationality, even if the loss is not only severe but permanent, it is on $1 \mathrm{y}$ this person who cannot live up to the vow. It does not seem that it follows that it would become impossible for the other to live up to the vow. If both spouses, however, suffer a severe and permanent loss of rationality, then of course the vow does become impossible to live up to by either spouse. In this case, it seems that the vow would still be in existence, but the peculiar kind of meaninglessness, which was mentioned above in reference to certain promises, would then be predicable of the vow.

The death of one or both spouses would mean the dissolution of the vow altogether, since the absence of a bearer would cause that person's claim and obligation to dissolve, and thus the relationship would cease to exist. It does not seem, as with promises, that anything can happen in the world, that is, rather 
than to one or both of the spouses, that would make the vow either impossible to live up to or that would cause it to cease to exist. The question of the obligation of the marriage vow being outweighed by a higher duty to act moral1y is not here relevant, because similar to promising, vowing that has an immoral content does not bring a vow into existence. Thus if the vow comes into existence then the content cannot be immora1. Further, it does not seem that it could ever become immoral. A vow would also not meet an end by being superseded by a higher duty to take care of an evil, for example. A specific action which one might be obliged to perform as a result of the vow could perhaps be outweighed by a higher duty to save a person's life, for example, but the obligation of the vow would never be completely superseded.

With respect to the act of promising, a question was raised as to whether the content of the promise had to be of interest to the promisee for the promise to come into existence. This question does not have a relevancy in the case of the marriage vow because as mentioned above, the vow must be reciprocated in order for it to even come into existence, and obvious $1 \mathrm{y}$ for one to reciprocate a vow one must be interested in the vow of the other.

Another question was how to evaluate the situation when the content of the promise was not on $1 y$ not of interest to the other, but against the interests of the other. It does not seem that the content of the vow could ever be against the interests of a person. On the other hand, the vow itself, the extra-menta11y existing bond, could indeed be against the interests of one or both persons. There 
are two separate cases here, one is that the proposed vow was against the interests of one or both persons from the time before the vow was even made. In this case, especially if a deception had occurred, it might be that the vow would not have come into existence at a11.

Secondly, the vow can come to be against the interests of one or persons. For example, one or both spouses might stop trying altogether to live up to the vow after a certain period of time has passed. In this case, 1imiting the discussion once again to natural reason, if both persons each waive their own claim through a completely voluntary and uncoersed act, then it seems that this would lead to the dissolution of the vow. ${ }^{88}$ If, though, only one of the spouses wished to be free from the vow, this would not then cause the vow to cease to exist, because of the fact that the vow has an extra-mental existence and is therefore independent of the feelings of either person.

Fina11y, the topic of promises that have conditions was analyzed. Does this have any application to the marriage vow? Can the marriage vow have a condition? Keeping within the realm of natural reason, it might be that just as one may be released from a promise by the call of a higher duty, for example, one may also be released from a marriage vow by something such as the total abandonment by one's spouse. Even if neither of these conditions are explicitly stated, they are still implicitly present. These conditions which need not even be mentioned can be referred to as basic conditions. 89 The question is, can there ever be conditions attached to the marriage vow besides these basic conditions? It 
seems that the answer is yes, as long as the condition is stated $\operatorname{explicit1y,~understood~and~agreed~to~by~both~parties~before~the~vow~}$ is made.90 An example of such a condition could be. "So long as you don't become a member of the Conservative Party".91

On the other hand, since the marriage vow is taken "til1 death do us part", it does not seem possible that the vow could have a time 1imit, although a promise oftentimes has this as a condition. The marriage vow also cannot have as a condition the death of either spouse, for obvious reasons. Furthermore, it seems that the possibility of a third party is precluded with the marriage vow. That is, it does not seem possible that there can be an addressee of the content of the obligation other than the person to whom the vow is made.

In conclusion, then, a1though the marriage vow is similar to the promise in many ways, nonetheless the marriage vow is different enough from the anaysis of the promise given by Reinach to cal1 it by a different name.

This paper has attempted to do justice to the superb analysis of the promise and the act of promising accomplished by Reinach, and perhaps rather than clouding the subject, has served rather to further uncover some of Reinach's insights. In addition, the nature of the promise and promising, and of the vow and the act of making a vow, have perhaps become clearer both as to their similarities and differences. 
ENDNOTES

1. Adolf Reinach, "The Apriori Foundations of Civil Law", Aletheia: An International Journa1 of Philosophy, Volume 3, (1983): 5 .

2. Ibid., 19 .

3. Both Dr.Wenisch and Dr.Roberts pointed out the ambiguity of the term "promise".

4. At times Reinach uses the term "promise" when the term "promising" is actual1y more accurate. For example, see page 28 of "The Apriori Foundations of Civil Law" where he states, "...a genuine promise can be performed and expressed, yet without reaching the subject to whim it is directed." and "If the promise is simply heard (vernommen) htere arises a claim in the one who hears and an obligation in the promisor."

5. Webster's Seventh New Collegiate Dictionary, Second ed., s.v. "promise".

6. Reinach, p.32.

7. Ibid., p.16-17.

8. Ibid., p.17.

9. Ibid., p.26.

10. Ibid., p.18.

11. Ibid.

12. Ibid.. p.20.

13. Ibid.

14. Ibid.

15. Ibid.

16. Ibid., p.36.

17. Ibid., p.29-30. 
18. Ibid., p.21-22.

19. Ibid., p.26.

20. Ibid., p.25.

21. Ibid., 22 .

22. Ibid.

23. Dietrich Von Hildebrand, Marriage, the Mystery of Faithful love, (Manchester: Sophia Institute Press, 1984): 17.

24. Reinach, p.33.

25. I am indebted to Mark Roberts for pointing out the various meanings of the term "objective".

26. Reinach, p.11.

27. Ibid., p.9.

28. Ibid., p.11.

29. Ibid., p.10.

30. Ibid., p.8.

31. Ibid.

32. Ibid., p.9.

33. Ibid., p.31.

34. Ibid., p.11.

35. Ibid.

36. Ibid., p.11-12.

37. Ibid., p.12.

38. Ibid., p.44.

39. Dr.Eritz Wenisch pointed this out to me.

40. Reinach, p.45.

41. Dr.Mark Roberts pointed this out to me.

42. Reinach, p.28.

43. Dr.Fritz Wenisch holds this to be the case. 
44. Ibid.

45. Reinach, p.34.

46. This is the view of Dr.Fritz Wenisch.

47. Reinach, p.32.

48. Ibid., p.45-46.

49. Dr.Mark roberts provided the examples of blindness, senility and coma.

50. This is the view of Dr.Fritz Wenisch.

51. Reinach, p.32.

52. Dr.Fritz Wenisch pointed out the fact that it might make a difference whether or not the promisor is aware of the immorality of the content and whether od not the content is intrinsically immoral or immoral due to external circumstances. He also gave as a condition for a promise to come into being that the content not be immora1.

53. Reinach, p.45.

54. This point springs from a comment made by Dr.Mark Roberts on the topic of a promise being suspended because the promisor is blind. He asked the fruitful question of what would happen if the situation changed during the time thye promisor was blind and the pgaintings were now in a museum in Japan.

55. Reinach, p.27.

56. Ibid., p.49.

57. On the other hand, such a promise in itself seems very possible. It might be that the analysis has to be adjusted to allow for such a promise.

58. Reinach, p.12.

59. Ibid.

60. Ibid., p.31.

61. Gwennyth Taylor, "On Doing What One Wants to Do," Canadien Journa1 of Philosophy, Volume 5, 1975): 442.

62. Dr.Fritz Wenisch pointed this out to me.

63. Reinach, p.11. 
64. John R. Sear1e, An Essay in the Philosophy of Language,

(Cambridge: Cambridge university Press, 1970): 59 .

65. Taylor, p.444.

66. Ibid.

67. This is the view of Dr.Eritz Wenisch.

68. Reinach says that "...an act of declining prevents both claim and obligation from coming into being." p.29.

69. Reinach, p.33.

70. Ibid.

71. Webster's New International Dictionary of the English Language, ed., s.v. "vow."

72. This is the view of Dr.Fritz Wenisch.

73. Susan Mendus, "Marital Faithfulness," Philosophy, Volume 59, (1984): 243 .

74. Dietrich and Alice Von Hildebrand, The Art of Living, (Chicago: Fransican Herald Press, 1965): 113.

75. Ibid., p.114.

76. Ibid., p.113.

77. Ibid.

78. Ibid., p.107, 109.

79. Ibid.. p.109.

80. Ibid., p.109-110.

81. Ibid., p.112.

82. Ibid.. p.108, 109.

83. Ibid., p.113.

84. Ibid., p.116.

85. Ibid., p.117.

86. Dietrich Von Hildebrand, p.17.l

87. Ibid.. p.5-16. 
88. Keeping within the limits of naural reason, this is the view of Dr.Fritz Wenisch.

89. These basic conditons were pointed out to me by Dr.Fritz Wenisch.

90. Keeping within the limits of natural reason, this is the view of Eritz Wenisch.

91. Mendus, p. 246. 


\section{BIBLIOGRAPHY}

Mendus, Susan. "Marita1 Faithfulness." Philosophy, Volume 59, (1984): 243-252.

Reinach, Ado1f. "The Apriori Foundations of Civil Law" Aletheia: An International Journal of Philosophy, Volume 3. (1983): $1-142$.

Searle, John. Speech Acts: An Essay in the Philosophy of Language. Cambridge: Cambridge University Press, 1970.

Tay1or, Gwennyth. "On Doing What One Wants to Do." Canadien Journa1 of Philosophy, Volume 5. (November 1975): 435-447.

Von Hilebrand, Alice and Dietrich. The Art of Living. Chicago: Fransican Hera1d Press, 1965.

Von Hildebrand, Dietrich. Marriage, the Mystery of Faithful Love. Manchester: Sophia Institute Press, 1984.

Webster's New International Dictionary of the English Language. Second ed., unabridged, s.v. "vow."

Webster's Seventh New Collegiate Dictionary, Second ed.. s.v. "promise." 